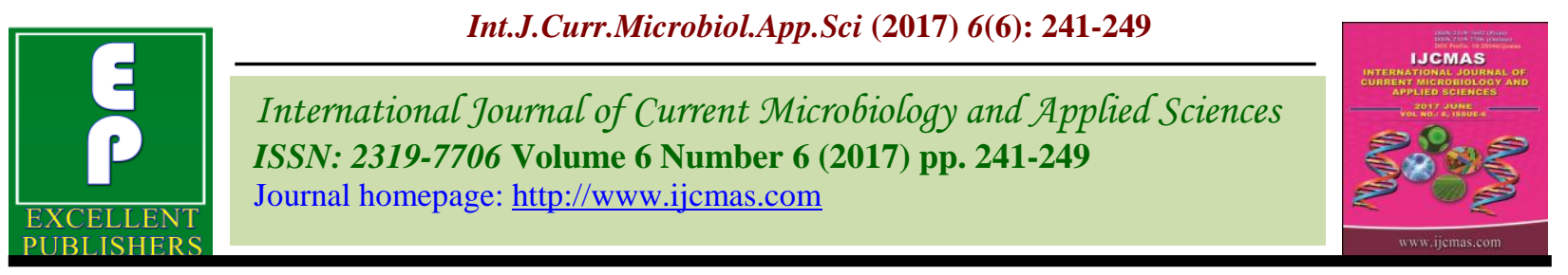

Review Article

https://doi.org/10.20546/ijcmas.2017.606.029

\title{
Development of Critical Limits for Different Crops Grown in Different Soils and Its use in Optimizing Fertilizer Rates
}

\author{
P.N. Siva Prasad ${ }^{1 *}$, C.T. Subbarayappa ${ }^{2}$, M. Raghavendra Reddy \\ and Hari Mohan Meena ${ }^{3}$
}

${ }^{1}$ Department of Soil Science and Agriculture Chemistry, GKVK, UAS (B), Karnataka-560065, India

${ }^{2}$ Department of Soil Science, GKVK, UAS, Bengaluru-560065, Karnataka-560065, India

${ }^{3}$ Department of Soil Science and Agriculture Chemistry, GKVK, UAS (B),

Karnataka-560065, India

*Corresponding author

\begin{tabular}{|c|c|}
\hline & A B S T R A C T \\
\hline & Soil testing is a useful tool that can help to ensure the efficient use of applied plant \\
\hline & $\begin{array}{l}\text { nutrients. Soil tests measure the quantity of a nutrient that is extracted from a soil } \\
\text { by a particular extractant. The measured quantity of extractable nutrient in soil is }\end{array}$ \\
\hline Soil testing, & then used to predict the crop yield response to application of the nutrient through \\
\hline $\begin{array}{l}\text { Fertilizer, } \\
\text { Extractants, }\end{array}$ & $\begin{array}{l}\text { fertilizer, manure and any other amendments. As soil test levels increase for a } \\
\text { particular nutrient the expected crop vield response to additions of that nutrient }\end{array}$ \\
\hline $\begin{array}{l}\text { Critical limits } \\
\text { and plant response }\end{array}$ & $\begin{array}{l}\text { decreases. A good soil test should be able to predict the amount of plant-available } \\
\text { nutrient as well as the fertilizer responsiveness of plant growing on a wide range }\end{array}$ \\
\hline Article Info & of soils. Predicting of plant response to fertilizers is traditionally determined by \\
\hline $\begin{array}{l}\text { Accepted: } \\
\text { 04 May } 2017 \\
\text { Available Online: } \\
\text { 10 June } 2017\end{array}$ & $\begin{array}{l}\text { Cate-Nelson graphical and Statistical method. The concept of critical limit } \\
\text { distinguishes deficiency from sufficiency, which could be employed to advice on } \\
\text { need for nutrient fertilization. The critical limits are quite often employed for a } \\
\text { wide variety of soils and crops and these critical limits differ not only for soils, }\end{array}$ \\
\hline & crop species but also for different varieties of a given crop. \\
\hline
\end{tabular}

\section{Introduction}

Literally the word fertile means 'bearing abundantly' and a fertile soil is considered to be one that produces abundant crops under suitable environmental conditions. Soil fertility is concerned with the inherent capacity of soil to provide nutrients in adequate amounts and in proper balance for the growth of specified plants when other factors such as light, moisture, temperature and the physical condition of the soil are favourable. Soil fertility is an aspect of the soil plant relationship viz., plant growth with reference to plant nutrients available in soil. Soil testing and plant analysis are useful tools for making recommendations for application of fertilizers to crops.

\section{Plant analysis}

Although plant analysis is an indirect evaluation of soil, it is a valuable supplement to soil testing. Plant analysis is useful in 
confirming nutrient deficiencies, toxicities or imbalances, identifying hidden hunger, evaluating fertilizer programme and determining the availability of elements. Sometimes adequate nutrients may be present in the soil, but because of other problems like soil moisture and inadequate amounts of some other nutrients, the plant availability of the nutrient in question may be constrained. For most diagnostic purposes, plant analyses are interpreted on the basis of critical value approach, which uses tissue nutrient concentration calibrated to coincide $90 \%$ or 95\% of the maximum yield, below which the plants are considered to be deficient and above that value sufficient

The approaches followed for predicting the fertilizer requirement of the crops includes

Many methods and approaches have been tried to get a precise and workable basis for predicting the fertilizer requirement of crops. Some of these are

General/blanket recommendations

Soil test ratings and fertilizer adjustments

Fertilizer recommendations for certain percentage of maximum yield.

Critical level of a nutrient in soil.

Fertilizer recommendation for maximum yield and profit

Fertilizer recommendation for targeted yields. DRIS (Diagnoses recommendation integrated system). Among the various approaches predicting of plant response to fertilizers is traditionally determined by critical soil test approach.

\section{Concept of critical limit}

Critical limit for the soil is defined as minimum soil test value associated with maximum crop yield. It is that the concentration below which deficiency occurs and it designates the lower end of sufficiency range.

Critical soil test value is the one which separates a group of soils which give significant yield response to fertilizers from that of soils which don't respond. Critical limit in plant refers to a level at or below which plant either develops deficiency symptoms or causes reduction in crop yields as compared to optimum yields.

\section{Critical limit is classified into 2 types}

Upper critical limits (UCL) - Toxicity after this.

Lower critical limits (LCL) - Deficiency below this.

\section{Purpose of developing critical limits}

Developed critical limits can be used in calibration and interpretation of soil testing i.e., to find deficient soils from non deficient and provides gives information on the nutrient status of soils.

The critical value approach is also useful for mapping soils over large areas where it is difficult for every farmer to get all his fields tested. Critical limit will help for revalidation of existing nutrient fertility ratings.

Critical limits will help for standardization and development of universally acceptable extractants for available soil nutrients.

\section{Different approaches of critical limits}

Two different approaches were introduced by Cate and Nelson:

Graphical method (1965) - Scattered diagram technique

Statistical method (1971) - R2 value 
Critical limit for soil by graphical method (1965)

The dry matter yields of crops was obtained at $100 \%$ flowering stage of crop age and was converted into Bray's percent dry matter yield by using the following equation.

Bray's per cent dry matter yield $=$

Dry matter yield obtained without Nutrient application

Dry matter yield obtained with optimum level of nutrient application

The critical level of nutrient in soil was derived by plotting the nutrient on ' $\mathrm{X}$ ' axis and Bray's percent yield on ' $\mathrm{Y}$ ' axis. A cross is placed over the data and moved to the upper left and lower right to have a minimum number of points (Cate and Nelson, 1965).

\section{Derivation of critical limits by statistical method}

Most soil testing laboratories divide soil test results into two or more classes for the purpose of making fertilizer recommendations. This procedure is to split the data into two groups (classes) using successive tentative critical levels to ascertain that particular critical level which will maximize overall predictive ability (R2), with means of two classes as the predictor values. In the statistical technique of determining critical level of nutrient, coefficient of determination (R2) was calculated. Accordingly the coefficient of determination (R2) was computed from the following relationship:

The steps followed for calculation of critical limit by statistical approach as suggested by Cate and Nelson (1971) were as follows.
The initial soil test values were arranged in ascending order.

The Brays per cent dry matter yield was written against each soil test value.

The correction factor (C.F.) and total corrected sum of square (T.C.S.S.) were calculated from Bray's per cent dry matter yield by using following formulae.

$$
\begin{aligned}
& (\square \mathrm{Y}) 2 \square(\mathrm{Y} 1+\mathrm{Y} 2+\mathrm{Y} 3 \ldots \ldots . . \mathrm{Yn}) 2 \\
& \mathrm{n} \\
& \text { T.C.S.S. }=\square \text { Yi2 }- \text { C. F }=\square(\mathrm{Y} 1+\mathrm{Y} 2+\mathrm{Y} 3 \\
& +\ldots \ldots \text {..Yn) } 2-\text { C.F }
\end{aligned}
$$

Where,

$\mathrm{Y}=$ per cent dry matter yield

$\mathrm{n} \quad=$ total number of observations

The data were grouped into two categories i.e. if the total number of observations are ' $n$ ' then data was grouped as (p, n-p), (p + 1, n-p1) e.g. if $\mathrm{n}=15$ then the data is grouped as (2, 13) $(3,12)$ $(13,2)$

A table with following columns were prepared

Last value of soil available nutrient.

Plant available nutrient included in population 1 st

$$
\begin{aligned}
& \mathrm{P} 1+\mathrm{P} 2 \ldots \ldots \ldots . \mathrm{Pn} \\
& \text { i.e. }=\text {-------------- } \\
& \mathrm{P}
\end{aligned}
$$

Combine sum of square of deviation from mean of population 1st i.e. C.S.S.I.

Here total of all values of population 1st was made

$$
\text { C.S.S.I. }=\square(\mathrm{P} 12+\mathrm{P} 22 \ldots(\mathrm{P} 1+\ldots \ldots . . . \mathrm{Pn} 2)-. .----
$$


If $\mathrm{Kn}$ was the number of observations in population IInd, then mean relative yield in population IInd

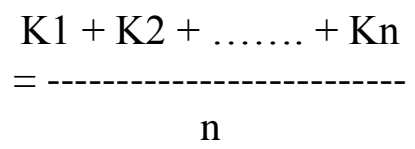

Combined sum of squares of deviation from mean of population IInd (CSSII). Here total of all values of population IInd was made i.e. $(\mathrm{K} 1+\mathrm{K} 2+\ldots \ldots+\mathrm{Kn})$

$$
\begin{array}{r}
\square(\mathrm{K} 1+\ldots \ldots . \mathrm{Kn}) 2 \\
\text { C.S.S.II }=\square(\mathrm{K} 12+\mathrm{K} 22+\ldots \ldots .+\mathrm{Kn} 2)-\cdot---
\end{array}
$$

Table.1 Soil fertility categories for organic carbon and available NPK

\begin{tabular}{lllcc}
\hline \multirow{2}{*}{ S. No. } & Soil Nutrients & \multicolumn{2}{c}{ Soil fertility ratings } \\
\cline { 3 - 4 } 1. & $\begin{array}{l}\text { Organic carbon as a measure of available Nitrogen } \\
(\%)\end{array}$ & $<0.5$ & $0.5-0.75$ & $>0.75$ \\
2. & $\begin{array}{l}\text { Available N as per alkaline permanganate method } \\
(\mathrm{kg} / \mathrm{ha})\end{array}$ & $<280$ & $280-560$ & $>560$ \\
& $\begin{array}{l}\text { Available P by Olsen's method (kg/ha) in Alkaline } \\
\text { soil }\end{array}$ & $<10$ & $10-24.6$ & $>24.6$ \\
& $\begin{array}{l}\text { Available K by Neutral N, ammonia acetate method } \\
(\mathrm{kg} / \mathrm{ha})\end{array}$ & $<108$ & $108-280$ & $>280$ \\
\hline
\end{tabular}

(Source: Muhr et al., 1965)

\begin{tabular}{|c|c|c|}
\hline Micronutrient & Indices & Range of Critical level (ppm) \\
\hline $\mathrm{B}$ & Hot water soluble & $0.5-1.0$ \\
\hline \multirow[t]{3}{*}{$\mathrm{Cu}$} & Mehlich No.1 & $0.1-10.0$ \\
\hline & $\mathrm{DTPA}+\mathrm{CaCl}_{2}(\mathrm{pH} 7.3)$ & $0.2-0.5$ \\
\hline & $1 \mathrm{~N} \mathrm{NH}_{4} \mathrm{OAc}(\mathrm{pH} 4.8)$ & 0.2 \\
\hline \multirow[t]{2}{*}{$\mathrm{Fe}$} & $\mathrm{DTPA}+\mathrm{CaCl}_{2}(\mathrm{pH} 7.3)$ & $2.5-5.8$ \\
\hline & $1 \mathrm{~N} \mathrm{NH}_{4} \mathrm{OAc}(\mathrm{pH} \mathrm{4.8)}$ & 2 \\
\hline \multirow[t]{4}{*}{$\mathrm{Mn}$} & Mehlich No.1 & $4.0-8.0$ \\
\hline & $\mathrm{DTPA}+\mathrm{CaCl}_{2}(\mathrm{pH} 7.3)$ & $1.0-2.0$ \\
\hline & $0.03 \mathrm{M} \mathrm{H}_{3} \mathrm{PO}_{4}$ & $0-20.0$ \\
\hline & $1 \mathrm{~N} \mathrm{NH}_{4} \mathrm{OAc}(\mathrm{pH} 7)$ & $3-4$ \\
\hline Mo & $\left(\mathrm{NH}_{4}\right)_{2} \mathrm{C}_{2} \mathrm{O}_{4}(\mathrm{pH} 3.3)$ & $0.05-0.2$ \\
\hline \multirow[t]{4}{*}{$\mathrm{Zn}$} & $0.1 \mathrm{~N} \mathrm{HCl}$ & $1.0-5.0$ \\
\hline & $1 \mathrm{~N} \mathrm{NH}_{4} \mathrm{OAc}(\mathrm{pH} \mathrm{4.6)}$ & $0.2-0.5$ \\
\hline & $\mathrm{DTPA}+\mathrm{CaCl}_{2}(\mathrm{pH} 7.3)$ & $0.5-1.0$ \\
\hline & $0.05 \mathrm{~N} \mathrm{HCl}$ & 1 \\
\hline
\end{tabular}

Table.2 Critical level of micro nutrients in soils

(Source: Fundamentals of Soil Science, 2009) 
Fig.1 Graph showing the limits of nutrient concentration and growth

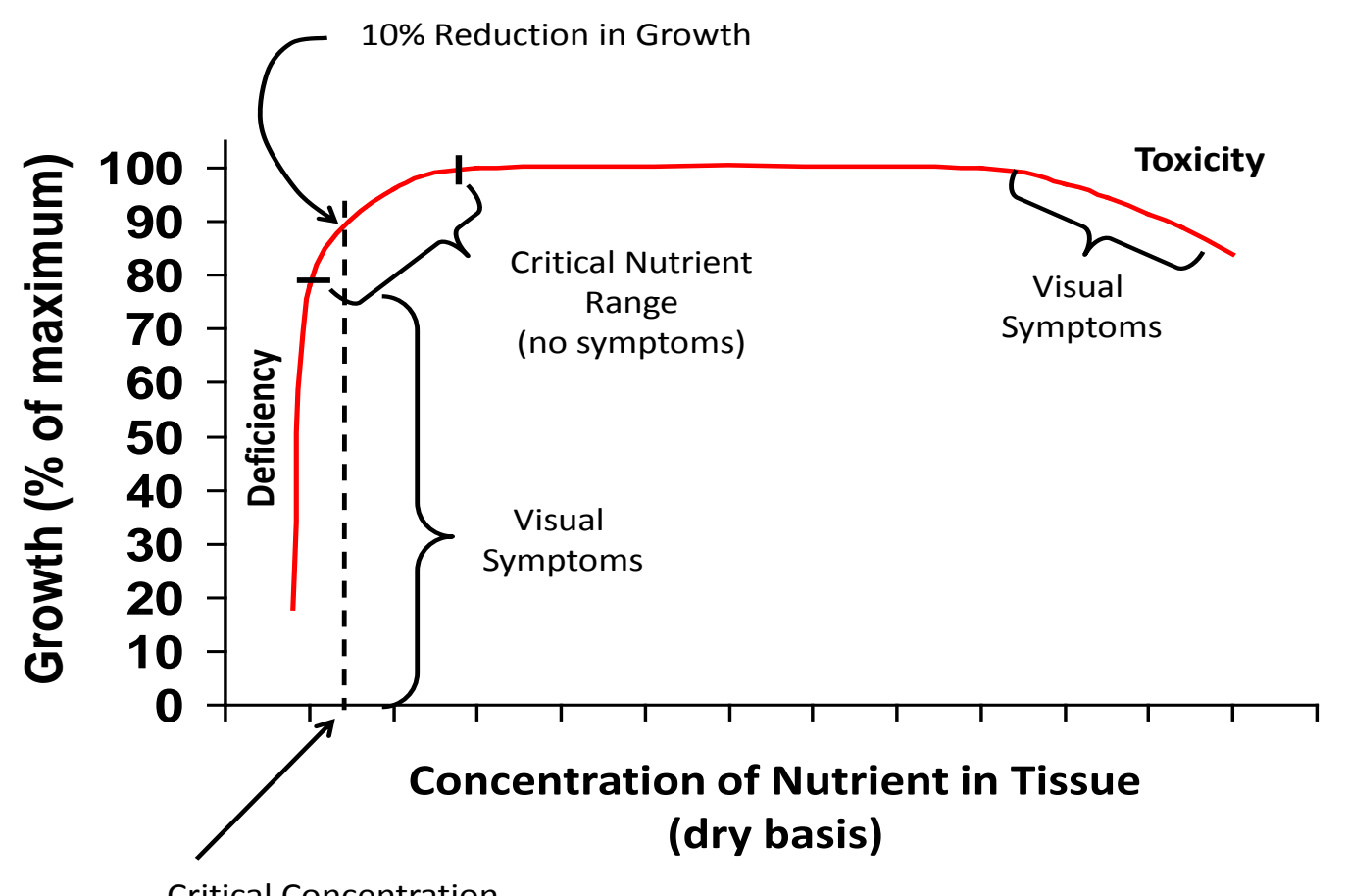

Fig.2 Response of fertilizers to different fertility status of soils Soil Test Interpretation Categories

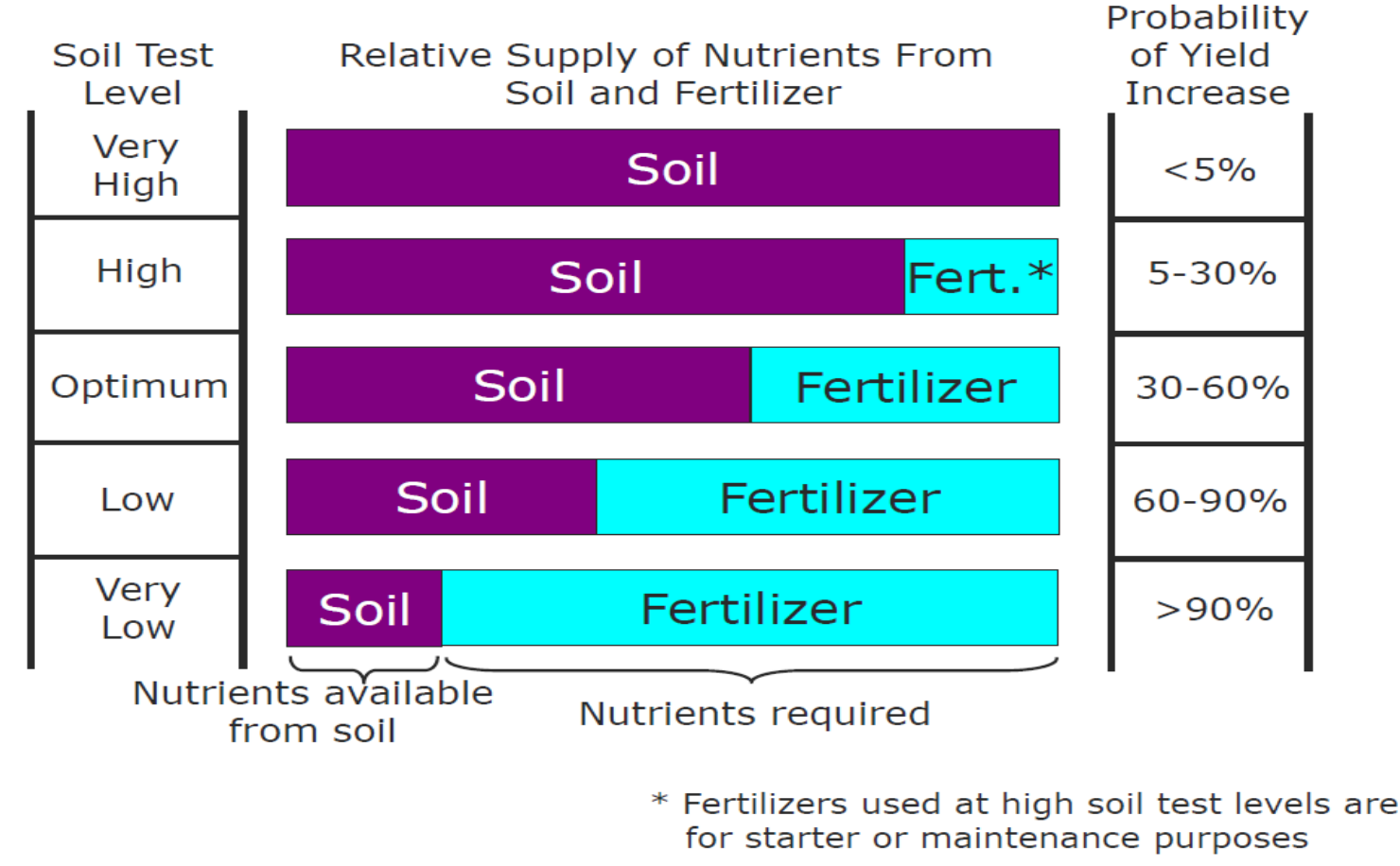


Fig.3 Graph showing critical limit by Graphical method

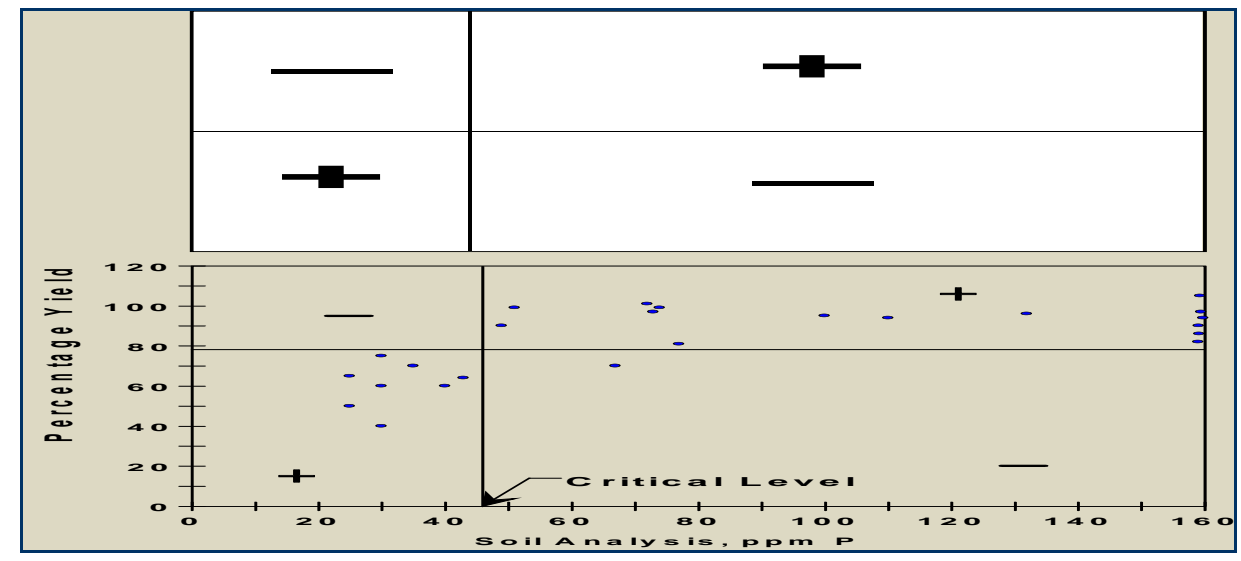

Postulated critical level (split between two populations) i.e. P.C.L. was calculated as

Last value in Ist population + value in IInd population

$$
\begin{array}{cc}
\mathrm{PCL}= & \mathrm{TCSS}-(\mathrm{CSS} 1+\mathrm{CSS} 2) \\
\mathrm{R}^{2}= & \text { TCSS }
\end{array}
$$

TCSS $=$ Total corrected sum of squares

CSS1 = Corrected sum of squares for population 1

CSS2 = Corrected sum of squares for population 2

The concentration having the highest $\mathrm{R} 2$ is the critical concentration. Due to diversified nature of soils, it is not possible to establish a fixed value of the critical limit for the available nutrient in different soils due to changed scenario by intensive cropping with high yielding varieties.

Using the Cate-Nelson graphical method, by Zare et al., (2009) the critical level of the extracted Zn by DTPA and EDTA for corn in non-saline soils in central Iran, were 1.5 and $1.17 \mathrm{mg} \mathrm{kg}^{-1}$, respectively and the highest yields were produced with the soils in which DTPA extractable Zn was between 1.2 and
$1.8 \mathrm{mg} \mathrm{kg}^{-1}$. In earlier studies critical level of 0.6, was reported for corn (Pal et al., 1989). Bado et al., (2010) reported that the critical limit of soil extractable $\mathrm{P}$ of $15.6 \mathrm{mg} \mathrm{P} \mathrm{kg}{ }^{-1}$ for Maize in low Acidic Ultisols of West Africa and fixed the critical limit by Cate and Nelson graphical method.

The statistically calculated critical level of soil $\mathrm{Zn}(0.83 \mathrm{ppm})$ for rice determined by DTPA extraction method was same as that of graphical method while the critical level values of $\mathrm{HCl}(1.8)$ and $\mathrm{NH}_{4} \mathrm{O}$ Ac $(0.40 \mathrm{ppm})$ extractable $\mathrm{Zn}$ varied considerably between graphical and statistical methods and thus it indicated that DTPA was better extractant for assessing available zinc status of calcareous soils (Rahman et al., 2007). Rakesh kumar et al., (2008) reported that critical value of 11.6 $\mathrm{mg} \mathrm{kg}^{-1}$ was optimum for $0.15 \% \mathrm{CaCl} 2$ extractable-S for green gram. Sanjeev and Raina (2008) established the critical range of 16-20 ppm DTPA extractable Zn for apple using the Cate-Nelson graphical model in Himachal Pradesh. Murthy et al., (2009) revealed that the critical level of DTPAextractable $\mathrm{Zn}$ of $0.325 \mathrm{mg} \mathrm{kg}^{-1}$ for castor in Alfisols grown in Ranga Reddy, Nalgonda, districts of Andhra Pradesh. Narayanaswamy and Prakash (2009) evaluated and summarized 
silicon ( $\mathrm{Si}$ ) fertilization of rice in different soils of south India. Initially, soils were analyzed using different extractants. The critical levels for plant available $\mathrm{Si}$ in the soil ranged from 14 $\mathrm{mg} \mathrm{kg}$ (distilled water-1) to $207 \mathrm{mg} \mathrm{kg}^{-1}$ [0.005 M sulfuric acid $\left.\left(\mathrm{H}_{2} \mathrm{SO}_{4}\right)\right]$. The NaOAc-1 and $0.5 \mathrm{M}$ acetic acid-2 were considered as the most suitable extractants for extracting plant available soil $\mathrm{Si}$ in rice soils of South India. There was a wide variation in low, medium, and high categories of plant available $\mathrm{Si}$ for different extractants calculated based on percent relative yield. The critical level of $\mathrm{Si}$ in straw and grain were 2.9 and $1.2 \%$, respectively

Subbarayappa et al., (2009) concluded that $\mathrm{P}$ content of $0.178 \%$ in leaf and $18 \mathrm{~kg} \mathrm{P}_{2} \mathrm{O}_{5}$ ha-1 of available $\mathrm{P}$ in soils could be considered as the critical limits for mulberry (S-36) variety. Similarly $\mathrm{Zn}$ content of $1.78 \mathrm{ppm}$ in soil and $27.1 \mathrm{ppm}$ in leaf could be considered as the critical limits for S-36 mulberry.

The critical concentration of soil available B and plant tissues B was 0.35 and $12.0 \mathrm{mg} \mathrm{kg}^{-1}$ respectively below which appreciable responses to $\mathrm{B}$ application were observed in rice grown in alluvial soils of west Bengal (Debnath and Ghosh, 2012).

Hosseinpur and Zarenia (2012) reported that $\mathrm{NH}_{4} \mathrm{OAc}$, AB-DTPA, $0.1 \mathrm{~mol} / \mathrm{L} \mathrm{BaCl}_{2}, 0.1$ $\mathrm{mol} / \mathrm{L} \mathrm{HCl}$ and boiling $1 \mathrm{~mol} / \mathrm{L} \mathrm{HNO}_{3}$ could not be used as available $\mathrm{K}$ extractants. But the correlation studies of distilled water, $0.1 \mathrm{~mol} / \mathrm{L}$ $\mathrm{HNO}_{3}$, Mehlich 1 and $0.01 \mathrm{~mol} / \mathrm{L} \mathrm{CaCl} 2$ with relative yield, plant response, concentration $\mathrm{K}$ and $\mathrm{K}$ uptake were significant. Therefore, these extracting solutions can be used as available $\mathrm{K}$ extractants. Potassium critical limits at $90 \%$ of relative yield were $22,190,28$ and $50 \mathrm{mg} / \mathrm{kg}$ for distilled water, $0.1 \mathrm{~mol} / \mathrm{L} \mathrm{HNO}_{3}$, Mehlich 1 and $0.01 \mathrm{~mol} / \mathrm{L} \mathrm{CaCl}_{2}$ respectively.

Mahata et al., (2013) concluded that the critical limit of DTPA-Zn in soil and 3rd leaf of rice plants was 0.82 and $28.5 \mathrm{mg} \mathrm{kg}^{-1}$, respectively. From the mean percentage response of $\mathrm{Zn}$ application, it is suggested that $\mathrm{Zn} @ 2.5 \mathrm{mg} \mathrm{kg}^{-1}$ should be applied to get optimum yields of rice in the soils of Terai zone of West Bengal.

Meena et al., (2013) concluded that application of $10 \mathrm{mg} \mathrm{kg}^{-1}$ iron recorded maximum mean dry matter yield of wheat. The Bray's percent yield in wheat plant which showed an increasing trend up to soil DTPA-extractable iron level of $4.67 \mathrm{mg} \mathrm{kg}^{-1}$ and after that it was decreased. The critical limit of iron is $4.67 \mathrm{mg} \mathrm{kg}^{-1}$ for soils of sub-humid southern Zone (IV-b) of Rajasthan. The critical limit of iron in wheat plant is $43.52 \mathrm{mg} \mathrm{kg}^{-1}$.

Chandrakala (2014) reported that the critical limit for available soil phosphorus $\left(\mathrm{P}_{2} \mathrm{O}_{5}\right)$ was $17.0 \mathrm{~kg} \mathrm{ha}^{-1}$ whereas for the critical concentration in maize plant was 0.12 per cent. Percent yield increase was higher when higher levels of P applied to very low and low P soils. Phosphorus uptake and dry matter yield by maize was significantly higher due to application of $125 \%$ rec. $\mathrm{P}+$ rec. $\mathrm{N}$ and $\mathrm{K}+$ rec. FYM in very low, low, medium and high $\mathrm{P}$ fertility soils The proposed fertility ratings for available phosphorus $\left(\mathrm{P}_{2} \mathrm{O}_{5}\right)$ were Very low (VL) - < $15.50 \mathrm{~kg} \mathrm{ha}^{-1}$, Low (L) - 15.51- 28.0 $\mathrm{kg} \mathrm{ha}^{-1}$, Medium (M) - 28.10- $48.50 \mathrm{~kg} \mathrm{ha}^{-1}$ and High $(\mathrm{H})->48.50 \mathrm{~kg} \mathrm{ha}^{-1}$.

Sakore et al., (2014) concluded that the critical limit of potassium in soil for brinjal plant was found $270.00 \mathrm{~kg} \mathrm{~K} \mathrm{ha}^{-1}$ by graphical method of Cate and Nelson and $274.40 \mathrm{~kg} \mathrm{~K}^{-1}$ by statistical method of respectively. The critical limit of potassium in brinjal plant at initiation of flowering for shrink-swell soils was found 2.36 per cent by graphical method and 2.39 per cent by statistical method. The results indicated that, soil containing less than $274.40 \mathrm{~kg} \mathrm{~K} \mathrm{ha}^{-1}$ and brinjal plant containing less than 2.39 per cent potassium at initiation of flowering, respond to application of potash fertilizers.

Meena et al., (2015) reported that the potassium application to sorghum significantly increased the dry matter yield in different locations viz., low, medium and high $\mathrm{K}$ soils. The low nutrient content soils responded more at $50 \mathrm{~kg} \mathrm{~K}_{2} \mathrm{O} \mathrm{ha}^{-1}$ 
followed by medium and high $\mathrm{K}$ status soils. Bray's percent yield and potassium uptake by sorghum plant were significantly correlated with available potassium. The critical limits of potassium in soil for sorghum as per graphical and statistical methods were 527 and $560 \mathrm{~kg}$ ha ${ }^{1}$ respectively, where as in sorghum plant were 2.10 and 2.08 per cent.

Mahendran et al., (2016) reported that the critical limit of boron was found to be $0.39 \mathrm{mg}$ $\mathrm{kg}-1$ in soil and $42.7 \mathrm{mg} \mathrm{kg}^{-1}$ in groundnut plant of Madurai district of Tamil Nadu. The added B was significantly affected on $\mathrm{N}$ and $\mathrm{B}$ content and uptake in groundnut pod and haulm. Also, the application of B to groundnut on B deficient soils enhanced pod filling and shelling percentage and protein content. Field experiment proved that the deficient soils showed significant response to the applied B. The pod yield of groundnut increased with increasing levels of $\mathrm{B}$ and the soil application of $20 \mathrm{~kg} \mathrm{ha}^{-1}$ of $\mathrm{B}$ as borax might be sufficient to alleviate the deficiency for groundnut in the district.

It is concluded due to diversified nature of soils, it is not possible to establish a fixed value of the critical limit for the available nutrient in different soils due to changed scenario by intensive cropping with high yielding varieties. In order to know the predictions on possible deficiencies, these critical limits must be defined and refined with reference to growing environment, certain soil characteristic and predefined plant parts of specific crops. The critical limits generated plays an important role in decision making at farm level planning particularly for the application of balanced nutrient to ensure the yield potential of crops.

\section{Acknowledgement}

The first author is highly grateful to the DST INSPIRE for the financial assistance given in the form of fellowship during the period of study. We thanks to the Department of Soil Science and Agricultural Chemistry, University of Agricultural Sciences, GKVK, Bengaluru,
Karnataka (India) for allotted Doctoral Seminar to me on critical limits development on different soils which is an initial framework for this review.

\section{References}

Bado, B. V., Lompo, F., Sedogo, M.P. and Cescas, M.P. 2010. Establishment of the Critical Limit of Soil-Available Phosphorous for Maize Production in Low Acidic Ultisols of West Africa. Commun in Soil Sci and Plant Anal. 41, 968-976

Cate, R.B. and Nelson, L.A.1965. A rapid method for correlation of soil test analysis with plant response data. International soil testing series technical Bulletin No. I North Caroline. State University, Agricultural Experiment Statistics, Releigh (USA). pp. 135-136.

Cate, R.B. and Nelson, L.A.1971. A simple statistical procedure for partitioning soil test correlation data into two classes. Soil Sci. Soc. Am. Proc., 35: 658-666.

Chandrakala.M., 2014. Status and revalidation of phosphorus requirement for finger millet- maize cropping system in soils of eastern dry zone of Karnataka. Ph.D (Agri) Thesis submitted to Univ. Agri. Sci., Bangalore.

Debnath, P. and Ghosh, S.K. 2012. Critical limit of available boron for rice in alluvial zone soils of west Bengal. Indian Journal Agricultural Research. 46 (3), 275 $-280$.

Hosseinpur, A.R. and Zarenia, M., 2012. Evaluating chemical extractants to estimate available potassium for pinto beans (Phaseolus vulgaris) in some calcareous soils. Plant soil environ, 58(1): 42-48.

Mahata, M.K., Debnath, P. and Ghosh, S.K., 2013. Estimation of Critical limit of Zinc for Rice in Terai Soils of West Bengal. J. Indian Soc. Soil Sci., 61(2): 153-157.

Mahendran, P.P., Velmurugan, R. and Balasubramaniam, P., 2016. Identifying critical limit in soil and plant for 
determining response of groundnut (Arachis hypogea) to boron application in Madurai soils of Tamil Nadu, India. J. Plant Nutrition, 39(2):163171.

Meena, R.K., Amrutsagar, V.M., Verma, M.K., Vishalseth, Meena, R., Maneesh Kumar. And Jat, L.K., 2015, Critical limits of potassium in soil and plant for increased productivity of Sorghum (Sorghum bicolor L.). Eco. Env. Cons., 21:371-377.

Meena R.S., Mathur A.K. and Sharma S.K.2013. Determination of critical limit of iron for wheat in soils of subhumid southern zone (IV-B) of Rajasthan Green Farming., 3: 298- 302.

Muhr G.R., Datta N.P., Shankar, Subramoney H, Liley V.K and Donahue R.L. 1965. Soil Testing in India.U.S. Agency for International Development, New Delhi, pp 120.

Murthy, I.Y.L.N., Padmavathi, P. and Padmaiah, M. 2009. Critical level of DTPA-Zn for castor (Ricinus communis L.) in Alfisols. Agropedology 19 (2): 139-142.

Narayanaswamy C. and Prakash N. B.2009. Calibration and Categorization of Plant Available Silicon in Rice Soils of South India. J. Plant Nutri, 32: 12371254.

Pal, A. R., Motiramani, D.P., Rathore, G.S., Bansal, K.N. and Gupta, S.B. 1989. A model to predict the zinc status of soils for maize. Plant and Soil. 116: 49-55.
Rahman, M.A., Jahiruddin, M. and Islam, M.R. 2007. Critical Limit of Zinc for Rice in Calcareous Soils. Journal of Agricultural and Rural Development 5(1\&2): 43-47.

Rakesh kumar, S., Karmakari and Prasad, J. 2008. Critical Levels of Sulphur for Green Gram (Vigna radiala) in Acidic Soils of Jharkhand. Journal of the Indian Society of Soil Science. 56 (4), 448-451.

Sakore G.D, Kulkarni R. V. and Pharande A. L. 2014. Evaluation of Critical Limits of Potassium in Soil and Plant for Kharif Brinjal Grown on Shrink-Swell Soils Trends in Biosciences 7(23): 3811-3817,

Sanjeev K. Chaudhary and Raina, J.N. 2008. Zinc transformation of and its critical limits in apple orchards of Himachal Pradesh. Journal of the Indian society of soil science, 56 (4), 430-435

Subbarayappa, C.T., Bongale, U.D. and Srinivasa, N., 2009. Determination of critical limits of phosphorus and zinc in soils and mulberry leaf. Karnataka J. Agric. Sci., 22(1): 95-98.

Zare, M., Khoshgoftarmanesh, A. H., Norouzi, M. and Schulin. R. 2009. Critical Soil Zinc Deficiency Concentration and Tissue Iron: Zinc Ratio as a Diagnostic Tool for Prediction of Zinc Deficiency in Corn. J. Plant Nutri, 32, 1983-1993.

\section{How to cite this article:}

Siva Prasad, P.N., C.T. Subbarayappa, M. Raghavendra Reddy and Hari Mohan Meena. 2017. Development of Critical Limits for Different Crops Grown in Different Soils and Its use in Optimizing Fertilizer Rates. Int.J.Curr.Microbiol.App.Sci. 6(6): 241-249. doi: https://doi.org/10.20546/ijcmas.2017.606.029 